\title{
GSTM4 Gene
}

National Cancer Institute

\section{Source}

National Cancer Institute. GSTM4 Gene. NCI Thesaurus. Code C105664.

This gene plays a role in the metabolism of both glutathione and xenobiotics. 